\title{
Encontros com Koellreutter: sobre suas histórias e seus mundos
}

\author{
IRENE TOURINHO
}

\author{
Primeiras impressões...
}

$\mathrm{H}$

Á QUEM DIGA que as primeiras impressões não resistem ao tempo. Outros insistem que o tempo geralmente confirma as impressões iniciais. Sem dúvida a questão é ambivalente, pois não é um processo que segue apenas uma lógica quantitativa. Outras condições somam-se ao tempo de construção dessas impressões. No caso dos encontros ocorridos com Koellreutter, além das 12 horas de gravação, também formaram as impressões que passo a expor referências culturais, musicais e pedagógicas anteriores.

Hans Joachim Koellreutter não pertence à categoria de indivíduo normal. A vida, o jeito de ser, o pensamento e a obra musical de Koellreutter revelam uma rebeldia que ora advém de acasos que preenchem sua história, ora se instaura a partir de suas ações e idéias deliberadamente críticas frente a outras histórias que se cruzam com a sua. Entendendo que "ser normal em nosso mundo é adaptar-se às prescrições, é não correr nenhum risco em busca da inovação, é temer o novo, o desconhecido" (Duarte Júnior, 1987:69), então Koellreutter está mais próximo da sanidade. Distante da loucura e transcendendo a normalidade estaria um caminho - até a sanidade - onde os indivíduos criadores "que não aceitaram aquilo que era dado" seriam encontrados (id., ib.).

Aquilo que seria uma entrevista convencional, com focos previamente delimitados e algumas questões seqüencialmente elaboradas, transformou-se - felizmente - em vários encontros nos quais o plano original foi adquirindo rumos inesperados que me colocaram diante de histórias de vida e pensamentos ainda pouco explorados em relação a Koellreutter. Assim, à medida que os assuntos iam aparecendo, minha curiosidade se intensificava.

Ao mesmo tempo em que havia um tom de imparcialidade na maneira como Koellreutter descrevia situações difíceis e conturbadas, suas decisões e reações pareciam estar envoltas em sensatez e justeza. Lembrava e comentava detalhes como se tudo estivesse completamente esclarecido tanto 
para ele quanto para quaisquer outros envolvidos nas cenas. O espanto causado por muitas de suas histórias provocava em minha mente uma sensação - incômoda - de que dificilmente conseguiria, via este discurso, condensar aquelas experiências, impressões e dúvidas que registrava.

Quando curiosidade e espanto se combinam encontramos o desejo de desvendar algo e, ao mesmo tempo, a condição de conviver com alguns mistérios. Em certas circunstâncias acatamos o que diante de nós se apresenta; às vezes, porque os mistérios nos seduzem e, outras, por entendermos que certos desvendamentos cabem melhor nos desejos de outros. Durante os encontros com Koellreutter, essas disposições me acompanharam. Elas se mantiveram enquanto relia e organizava o material para elaborar este texto e sinto que permanecerão comigo durante algum tempo.

\section{Definindo os rumos dos encontros...}

A persistência de uma sensação na qual curiosidade e espanto se combinavam orientou, naqueles encontros, minha vontade de ouvir Koellreutter como um indivíduo comum. Em parte, significou escutá-lo falar de assuntos e casos que lhe interessavam, quase me restringindo a registrar suas razões e versões. Mas significou, também, imergir em tais assuntos para transformar em perguntas meu desejo de conhecer esferas menos públicas de sua vida e de suas maneiras de pensar e agir.

Neste texto apresenta-se parte dos registros obtidos nos encontros realizados (1), privilegiando os relatos que normalmente não figuram em seus trabalhos (Koellreutter, 1982; 1985; 1991; 1995; 1997), em textos referentes à história da música brasileira, ou em comentários e análises de sua produção e atuação profissional (Squeff, 1985; Mendes, 1991; Contier, 1991; Chaves, 1996). Pelos relatos que ouvi, Koellreutter mostrou-se como um indivíduo pouco comum, cujas peculiaridades e minúcias das suas experiências de vida se misturam com atividades e influências que exerceu no movimento artístico-musical do país, podendo indicar nexos que as perspectivas históricas contemporâneas têm se proposto a investigar.

\section{Curiosidades...}

Cidadão carioca, nascido na Alemanha, doutor honoris causa das Universidades Federais da Bahia e do Ceará, professor, compositor e esteta, Koellreutter também é nome de uma árvore - Koelventeria paniculata - e guarda, ainda pelo nome, proximidade com um peixe e com uma pequena cidade da fronteira entre "Suíça e Áustria... ou Alemanha e Áustria... . não 
me lembro bem agora..." Dentre os descendentes suíços e alemães daquela cidade, os músicos eram principalmente conhecidos entre os suíços: "acho que trocaram o neném", brinca Koellreutter.

O encontro com a árvore foi um acaso. Num consultório de odontológico, quando morava no Japão, viu pela primeira vez a Koelrenteria paniculata. Da Basiléia, onde também soube da existência da árvore, trouxe mudas que hoje crescem no Rio de Janeiro e em Tiradentes (Minas Gerais), duas cidades que dividem, com São Paulo, o tempo do professor. Aos alunos, ele aconselha: "não acreditem em nada que um professor diz". Confessa, entretanto, que era "péssimo aluno na escola" e que "no colégio secundário, como socialista, tirei dinheiro dos meus colegas para comprar bananas de chocolate para os pobres".

Hoje, este jovem socialista declara que "o fundo de tudo que eu faço é um paradigma holístico... tudo está subordinado à minha filosofia holística" (2). É com base em tal paradigma que ele justifica sua opção por viver neste país: "me sinto membro, componente do Terceiro Mundo. A consciência aqui é mais ampla, mais aberta". Tendo recusado "muitas ofertas", Koellreutter avalia: "posso servir melhor à sociedade no Terceiro Mundo".

Sobre outros países onde trabalhou, entre eles Japão, Alemanha e Índia, Koellreutter pensa que "são mais estreitos, mais fechados". Ressalta, porém, que "o respeito ao ser humano aprendi no Japão... e sempre admirei isto neles". Comparando, fala que "o oriental se distancia bem das coisas que ele tem que viver... mas não é o respeito, como no Japão. É outra coisa".

Mesmo sendo muitas as marcas que cada lugar onde viveu deixaram, sobre os projetos e as realizações Koellreutter insiste: "desde que comecei a pensar em relação a mim mesmo, minhas idéias não mudaram; ... mudaram, mas são coerentes". Com esta mesma firmeza ele fala também sobre seu trabalho: "eu defino qual é a função da arte: uma atividade que supõe a criação de sensações, emoções e estados de espírito, em geral de caráter estético, assim como processos temporais conscientes que proporcionam ao ser humano o conhecimento e a vivência do mundo externo".

Mesmo decidida a restringir-me às suas idéias e razões, ficou evidente que não interessava a Koellreutter discutir essas ou outras idéias que expunha. Algumas vezes eu reafirmava, em tom de pergunta, algo que ele acabara de dizer, buscando confirmações, detalhes ou possibilidades de aproximar-me de razões ainda não ditas. O perigo de singularizar função em relação à arte, a carga ideológica vinculada à expressão Terceiro Mundo e a 
medida de limite sobre a inutilidade do discurso de professor foram exemplos de idéias que, quando recolocadas, provocavam uma rápida pausa, interrompida com a continuidade de sua fala incisiva: "arte é um elemento de comunicação". Incumbindo-se da pergunta seguinte, prosseguia: "comunica o quê?? Uma informação. Uma obra de arte que não comunica uma informação não é obra de arte".

Insistindo na busca, deixei soar a repetição de uma palavra: ...informação...? A resposta parecia pronta: "informação é uma mensagem de algo novo ou pouco conhecido". Sujeito desse tipo de comunicação, a fala do artista vem rápida: "minha função na sociedade em que atuo é a conscientização por meio da minha arte - daquilo que faço - e também por meio da pedagogia - do quê faço como pedagogo; comunicar as grandes idéias do século XX, em todas as áreas: nas ciências, nas artes, na filosofia e assim por diante..." Conscientizar e comunicar as grandes idéias do século em todas as áreas são objetivos que o músico-professor afirma de maneira que tanto pode ser interpretada como uma pretensão vaidosa quanto uma aspiração. Para ele, “é isso, pronto!”

Nesta época, na qual a relativização é quase tomada como um princípio impregnando qualquer discussão, a maneira assertiva com que Koellreutter expunha suas idéias e apresentava definições gerava desconforto. Ao mesmo tempo, como uma espécie de atração entre opostos - tal postura contracorrente - aguçava minha curiosidade. Aquele homem, com tantas idéias, tantas histórias em tantos lugares, tantas obras, guru de tantos músicos e mentor de rupturas nas formas de conceber a música e a composição musical, alternava seu jeito de ser entre ora sereno, ora áspero. Mas essa alternância não abalava sua posse de certezas.

\section{Particularidades...}

Conforme Koellreutter contava partes de sua vida, ficava aparente que a ousadia - de atitudes e de posturas - era uma das marcas mais fortes de sua personalidade. Ele relembra que sua "paixão pela música" nasceu durante um período de seis ou sete meses em que ficou praticamente preso num quarto da casa onde vivia, por decisão do pai, como castigo pelas notas obtidas na escola e pelo roubo do dinheiro dos colegas. “...Não podia brincar, nem conversar com ninguém... só podia estudar. Tinha apenas 12 anos". No quarto, "enquanto brincava com as coisas dos armários, descobri uma flauta militar, vertical, como flauta doce - um instrumento austríaco... Como criança, eu não podia ficar ali... Então tocava flauta! Quando saí da 'prisão' resolvi que ia ser músico". 
Entre a decisão tomada e a chegada ao Rio de Janeiro, já como músico experiente, muitos acontecimentos foram marcando a sua vida. Ele conta: "fui mandado para o Rio por causa de um amor". Os fatos que precedem essa história de amor, porém, são intrigantes. Com a expressão de certa forma abalada, Koellreutter relembra: "não tive minha mãe, que morreu em 1918 com a chamada gripe espanhola - a epidemia. Meu pai casou-se de novo, com uma mulher de quarta ou quinta categoria". Tal julgamento vinha amparado por outras revelações: "fui noivo de uma meiajudia. Combinada com meu pai, minha madrasta me denunciou à Gestapo; quer dizer, então, minha família me denunciou!”

Outros pedaços vão sendo incorporados à sua história: “fui expulso da Academia Estadual de Música de Berlim porque me neguei a integrar uma associação de estudantes - tipo UNE, aqui do Brasil, só que lá eram todos jovens nazistas. Já estudava flauta em Genebra e fui a Berlim renovar meu passaporte - tinha saído da Alemanha mas era época de me apresentar, obrigatoriamente, para o serviço militar. Chegando lá, um funcionário do Ministério da Guerra me mostrou a papelada da denúncia. Constava, como acusação da família, a denúncia de 'crime de desonra racial'". Koellreutter repete, como se quisesse certificar minha compreensão sobre esta informação: “... crime de desonra racial.”

Esse funcionário permitiu que Koellreutter fosse para casa "pensar se queria mesmo continuar com o noivado e, então, arcar com as conseqüências". Dois dias depois, ao comunicar a decisão de que manteria o noivado, "ouvi o funcionário dizer que já esperava isto de mim". Com um passaporte ilegal que o levaria ao consulado na Suíça, conseguiu garantir a sua saída da Europa: "liguei para meu pai antes de embarcar para a América Latina e lhe disse que queria me despedir dele. Ele impôs a condição de que eu aceitasse também a minha madrasta. Eu não aceitei e disse: então não me despeço de você. Quando saí, ao passar pela fronteira e sabendo que já não me pegariam, cantei... cantei muito! Cantava: Estou livre! Estou livre!”

Ousadia e firmeza mesclam-se nas tramas de vida que Koellreutter foi narrando. Já sem a mulher ("que decidiu voltar para a Alemanha... . não sei como concordei...") e também pressionado para retornar a seu país, foi taxativo: "não quero cruzar a fronteira daquele país enquanto Hitler estiver lá. Fui chutado da embaixada - chutado mesmo - por um funcionário". Muitos anos depois desse episódio, passando por Curitiba, Koellreutter seria convidado para um almoço na casa do cônsul da Alemanha, juntamente com o então diretor do Instituto Goethe. O tempo parece se responsabilizar por algumas surpresas: "reconheci o nome... era aquele funcionário que havia me dado o chute". 
"O almoço aconteceu e não se falou naquele assunto". Repeti, confirmando: ...e não se falou no assunto...? "Eu sou assim, principalmente pela experiência que tive em outros países... passar por cima, ver as coisas com uma certa distância, compreendendo o ser humano com suas inseguranças, seus erros". Ele exemplifica essa sua maneira de ser por meio de várias experiências. Logo que o Brasil entrou na guerra, enquanto estava preso na Estação da Luz em São Paulo, "ao lado de inimigos que apoiavam Hitler e, portanto, recebiam tratamento especial, eu compunha no meu leito - o terceiro superior daquelas tricamas - ... escrevia o tempo todo! Eles me odiavam porque eu estava sempre de bom humor".

Esse distanciamento das coisas e o bom humor não são, entretanto, as características mais evidenciadas quando falam sobre Koellreutter. Dizem que é, acima de tudo, polêmico. Diante de tal comentário, reage: "não faço polêmica pela polêmica. Quem diz isto não me conhece! Acho que a opinião dos outros é tão importante quanto a minha opinião". Convicto, reforça e amplia a idéia: "aprendi também com meus adversários em outros países".

Aprender com os adversários é a posição que Koellreutter procura demonstrar mediante uma cena, relatada com detalhes: "quando voltei para o Brasil - meu último posto na direção do Instituto Goethe foi o Japão minha secretária no Rio, hoje mulher do Edino Krieger, me disse: 'olha, depois de 15 anos fora do Brasil você precisava visitar o Museu da Imagem e do Som'. Eu detesto museus, essas coisas. Ela sabia e insistia: 'você tem que fazer uma apresentação lá'. Era uma novidade isso de museu de imagem e som".

Com Koellreutter convencido, passaram a planejar o evento: "ela sugeria que a diretoria do museu e alguns amigos que eu convidasse fossem assistir. Eu disse: também posso convidar inimigos! Ela sabia do meu conflito com Camargo Guarnieri e que os jornais me chamavam de nazista, comunista... Tinha também um jornalista que me atacou durante dez anos e era crítico do Correio da Manhã. Era um adversário profissional e me atacou estética, musical e até politicamente".

Relata então, com imponência, a cena na qual os adversários assumiram o lugar privilegiado: "no dia, estavam todos e o jornalista também. Pediram que antes de iniciar eu desse um testemunho sobre minha vinda ao Brasil, que explicasse os porquês. Pedi para fazer uma observação antes e disse: quero agradecer aos meus inimigos por tudo o que fizeram comigo. Se não fosse isso eu não teria feito tudo que fiz. Devo à oposição que me fizeram durante tantos anos. Com isto me fizeram estudar muito". 
Homenagear adversários publicamente não significa aproximação de idéias, um necessário começo ou recomeço de amizades - conforme Koellreutter faz questão de explicar. Um exemplo desse fato é sua relação com Camargo Guarnieri. Juntos, esses dois compositores foram destaque e alvo de polarizações enquanto idealizadores de rumos composição, ensino, relação com a sociedade - da atividade musical no país. Análises históricas que tratem da música brasileira durante o período que deu início ao movimento de criação do Grupo Música Viva (1939) até a Carta Aberta aos Músicose Críticos do Brasil (1950), dificilmente negligenciariam as polêmicas entre Guarnieri e Koellreutter.

Quando o nome de Camargo Guarnieri entrou na conversa, Koellreutter parecia indeciso sobre como abordar esse assunto. Um tempinho parado e, sem muitos mistérios, inicia suas re-

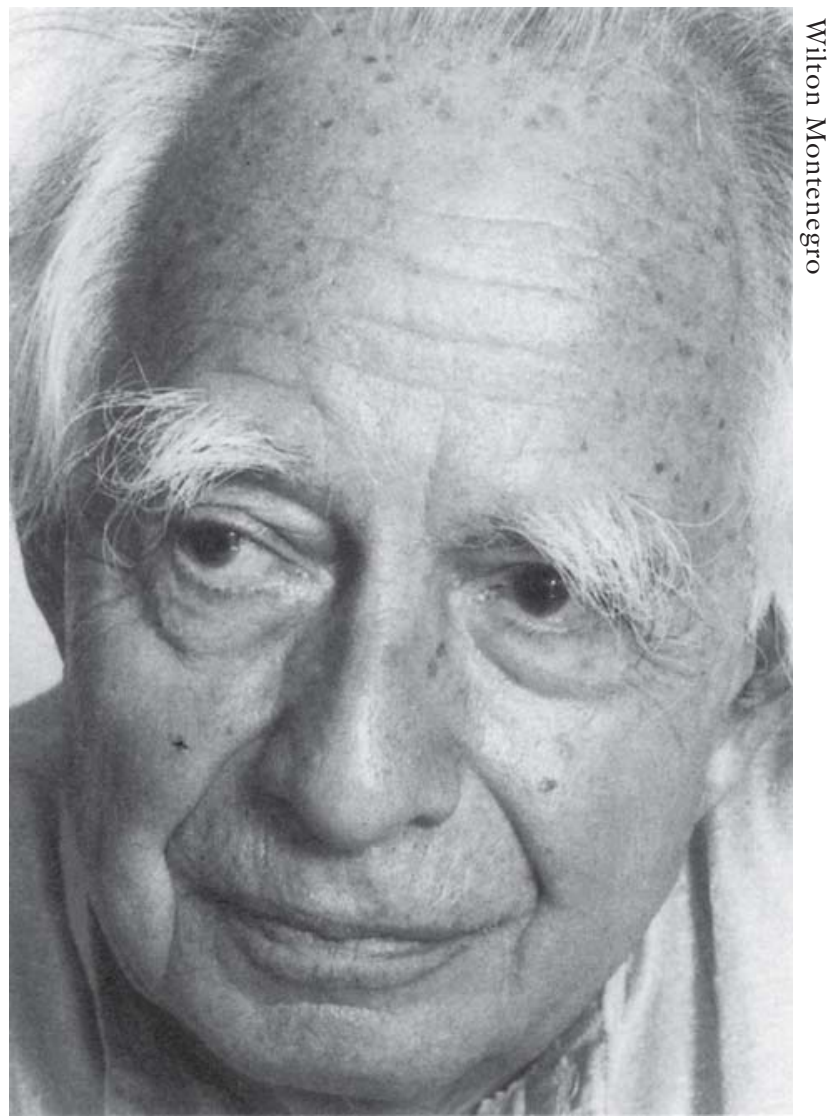

Hans-Joachim KOELLREUTTER cordações: "eu era muito amigo do Camargo". Em tom de reconhecimento conta: "durante um período em que estive gravemente doente (3), quem me visitou quase diariamente foi Camargo Guarnieri. Fomos muito amigos nessa época". Como sinal desta amizade, diz que "um dos folhetos do Grupo Música Viva foi dedicado a Camargo Guarnieri”. Mas o rompimento da relação tornou-se emblemático para a análise de distinções estéticas, musicais e ideológicas de um grupo atuante de compositores daquela época. Seu comentário sobre o assunto tem ares de chacota: "não sei como surgiu... Dizem que foram as mulheres que brigaram..." Machista...? Ele apenas riu.

Reencontrar Guarnieri foi iniciativa sobre a qual Koellreutter se gaba. Ele viria a saber, por meio de Caio Pagano, que o Curso Internacional de 
Férias de Teresópolis faria um concerto em homenagem aos 70 anos de Camargo Guarnieri. "Pedi que ligasse para ele e o convidasse para um concerto dividido: metade Koellreutter, metade Camargo Guarnieri. Ele aceitou, fizemos, depois almoçamos e conversamos. Mas não ficamos amigos". Não houve, da parte de Koellreutter, reivindicação de sinceridade nem tampouco disposição para falar ou oferecer mais informações sobre essa ou outras polêmicas que envolveram seu nome.

Supersopisão dos diagramas:

$\mathrm{UT}=$ Unidade de tempo a critério do intérprete

$O$ = Som ou pausa de duração de 1-2 unidades de tempo

$\triangle=$ som, pausa ou silêncio de 4-8 unidades de tempo

= som ou silêncio de 10-20 unidade de tempo

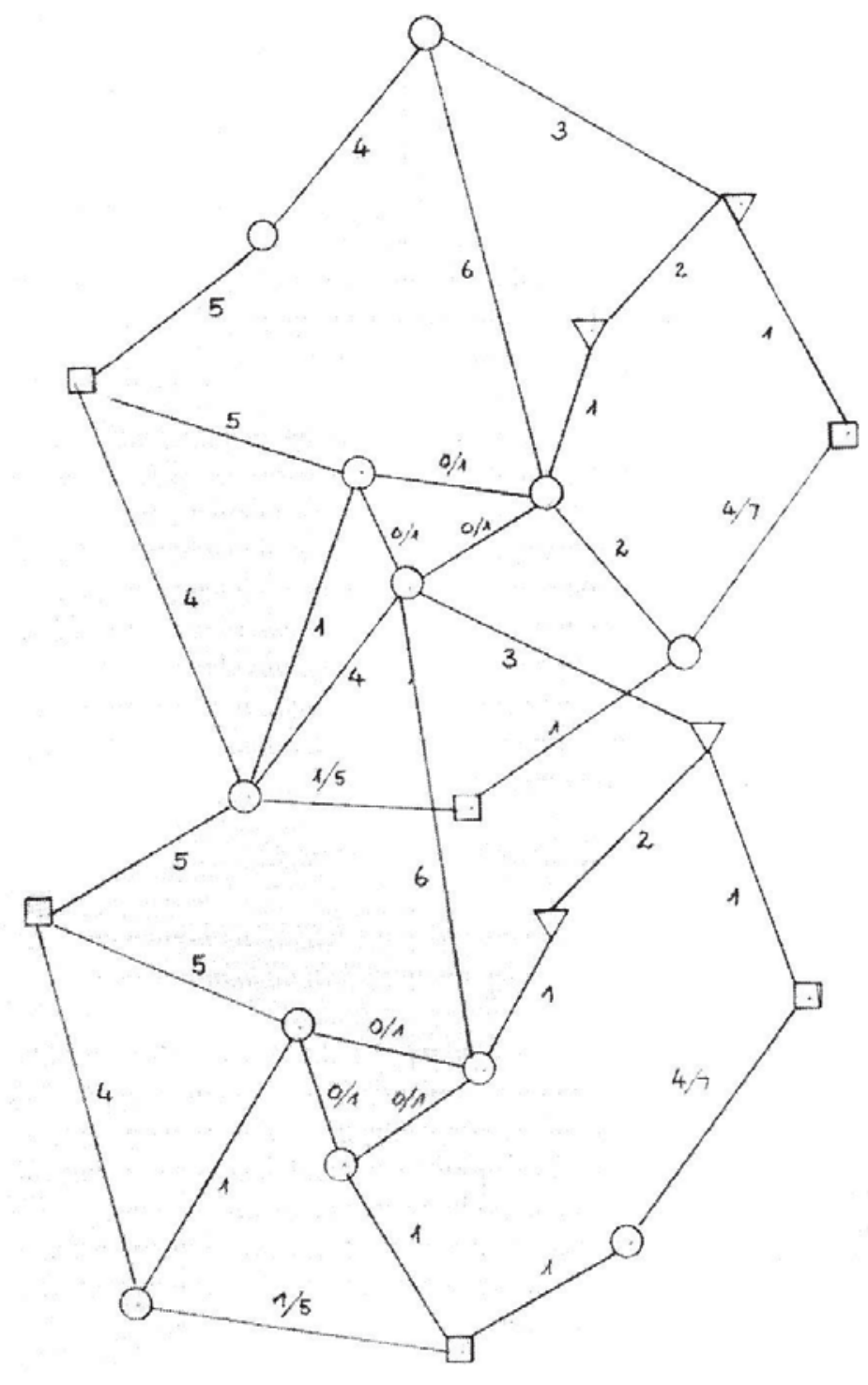




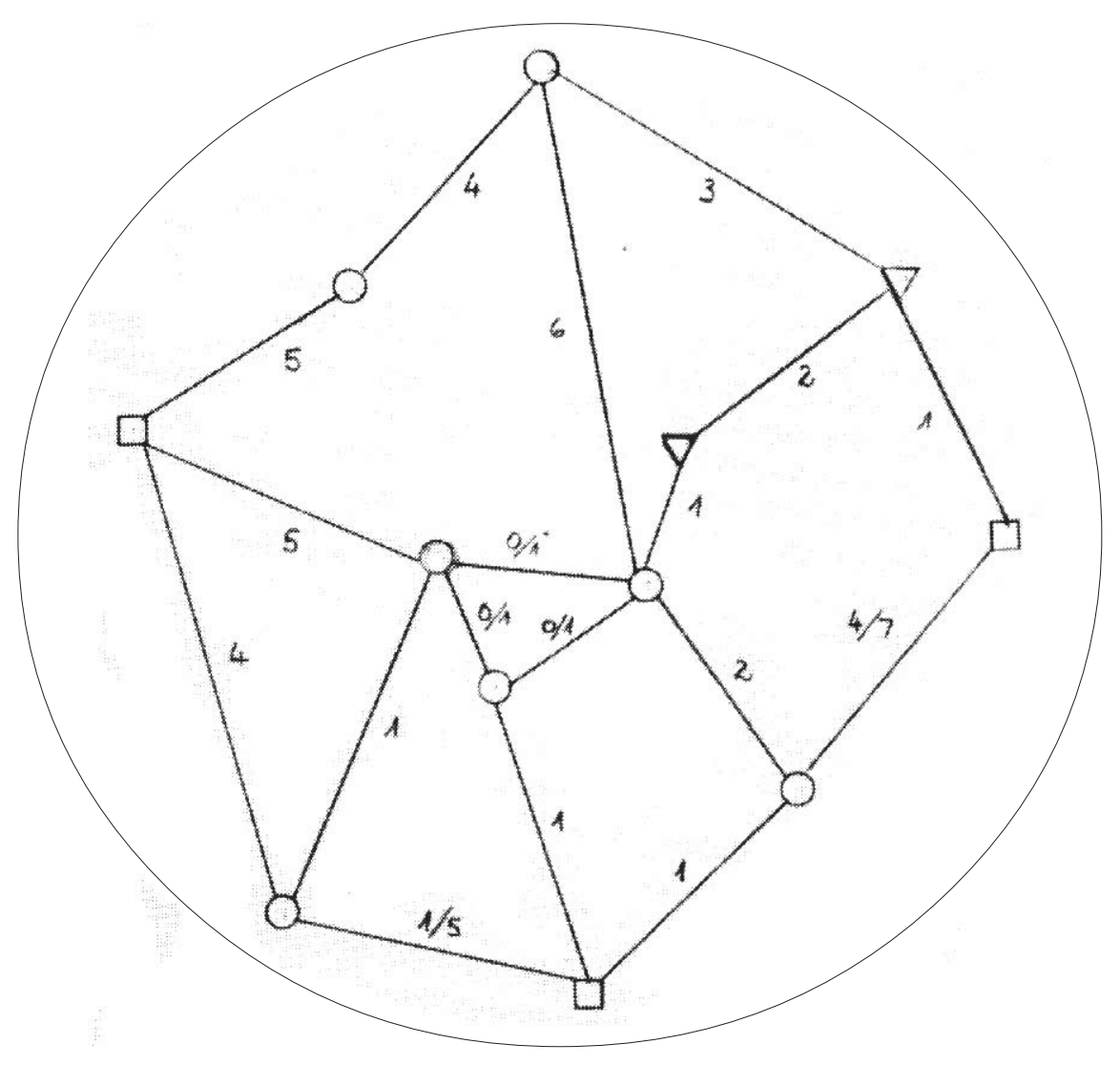

Diagrama K (Wu-li)

Os algarismos ao lado das linhas de trajeto referem-se à duração das trajetórias de silêncio, pausa ou som em unidades de tempo.

As entradas dos instrumentos ou vozes ocorrem a critério dos intérpretes; da mesma forma densidade ou rarefação da polifonia.

Os sons de altura definida ou indefinida obedecem à tessitura dos instrumentos ou vozes respectivos, subdividida em sons graves, médios ou agudos.

\section{Algumas idéias, atividades e perspectivas...}

Direto, mas sem irritação, ele diz: "detesto ler coisas sobre mim mesmo. É um complexo, talvez. Tenho outro defeito. Como moro em São Paulo, no Rio e um pouquinho em Tiradentes, têm pessoas que vêm me amolar em todas essas cidades". Resumindo, concluiu: "eu me auto-analiso. Diria que sou o produto de uma oposição, de uma revolta contra a burguesia da minha família - que não era nazista mas nacionalista alemã, monarquista”. 
Viver essa revolta incluiu, entre outras atividades, "ser vendedor na Casa e Jardim e trabalhar no almoxarifado da empresa, na Barão de Itapetininga, cujo proprietário, Theodoro Heuberger, também foi preso quando o Brasil entrou na guerra. Fiz caixotes, limpei janelas e vendi vasinhos importados da Alemanha - pequenos souvenirs". Depois, "tocava à noite na Lapa, no Danúbio Azul, um restaurante".

Durante algum tempo, entre o Rio de Janeiro e São Paulo, tocava na Orquestra Sinfônica Brasileira e ensinava. Ficou dez anos na Bahia, conforme contabiliza sem muita segurança: "eu não escrevo diário e isso é um problema..." Mas faz questão de corrigir: "algo que entrou em toda bibliografia sobre mim e não está correto: dizem que fui aluno de Hindemith! Eu assisti um curso de extensão que Hindemith deu sobre a nova teoria; mas eu era um dos muitos que fez isto!" Enfático, esclarece: "quem me levou à música nova foi o maestro Hermann Scherchen - fez análises e me levou à música moderna. $\mathrm{E}$ a discussão sobre o dodecafonismo era corrente em todos os lugares".

Do apartamento amplo, discretamente mobiliado, Koellreutter pode ver a avenida São Luiz, centro de São Paulo. A tradição do lugar convive, nos dias de hoje, com imensos palcos cercados de caixas de som onde grupos musicais diversos animam uma multidão que dança horas seguidas. De dentro, Koellreutter não parece perturbado e lança, seguro, idéias que misturam tradição e inovação, tratando de futuros que parecem tão possíveis para ele quanto para seus alunos.

Fala como professor, refletindo sobre as relações entre artista e universidade: "muitos alunos me perguntam se devem ir para a universidade. Digo: vocês não estudam música para seguir aquilo que a academia ensina, mas para opor-se àquilo que ela quer ensinar. Estudem harmonia para contrariá-la. Esta é minha convicção: têm de aprender as regras da academia para saber como devem mudá-las para a criação de um mundo novo. Se não conhecem as regras, as marcas dos estilos anteriores, não podem criar algo novo. Precisam saber o tradicional para criar algo de novo. É realmente algo, não é tudo novo".

Nele, essa postura transformadora não desconsidera e nem reverencia o passado: "conhecer as regras e saber porque elas existem. Elas não são brincadeiras. Ligeti escreveu a peça para o filme 2001 - Odisséia no Espaço. $\mathrm{Na}$ introdução ele escreve que aprendeu aquela música estudando as partituras de Palestrina. É lógico que você não ouve nada de Palestrina, mas os princípios teóricos de comunicação e estética, que são básicos e fundamentais, estão ali”. 
Mesmo ardoroso na sua defesa sobre a constante necessidade da criação, da subversão de regras e da proposição de mundos novos, aceita - neste caso - a existência de limites concretos para tais possibilidades de ações. Com calma, cria uma imagem desses limites: "nossa vida cultural é como uma grande lagoa. Nós todos jogamos pedras - algumas grandes e outras pequenas. Todas são igualmente importantes para movimentar esta grande lagoa".

Koellreutter jogou algumas pedras na lagoa musical brasileira, gerando movimentações significativas, respingos e, talvez, outras lagoinhas que continuam a se movimentar. Sobre uma dessas primeiras pedras - a criação do Grupo Música Viva -, dois anos após ter chegado ao Brasil - ele observa: "existem pequenos mal-entendidos. Pensavam que era um conjunto de pessoas que se dedicava àquilo que em 1937 era contemporâneo. Não é verdade! O grupo foi fundado para divulgar e difundir música de todas as épocas, música desconhecida... naturalmente aquela também...”

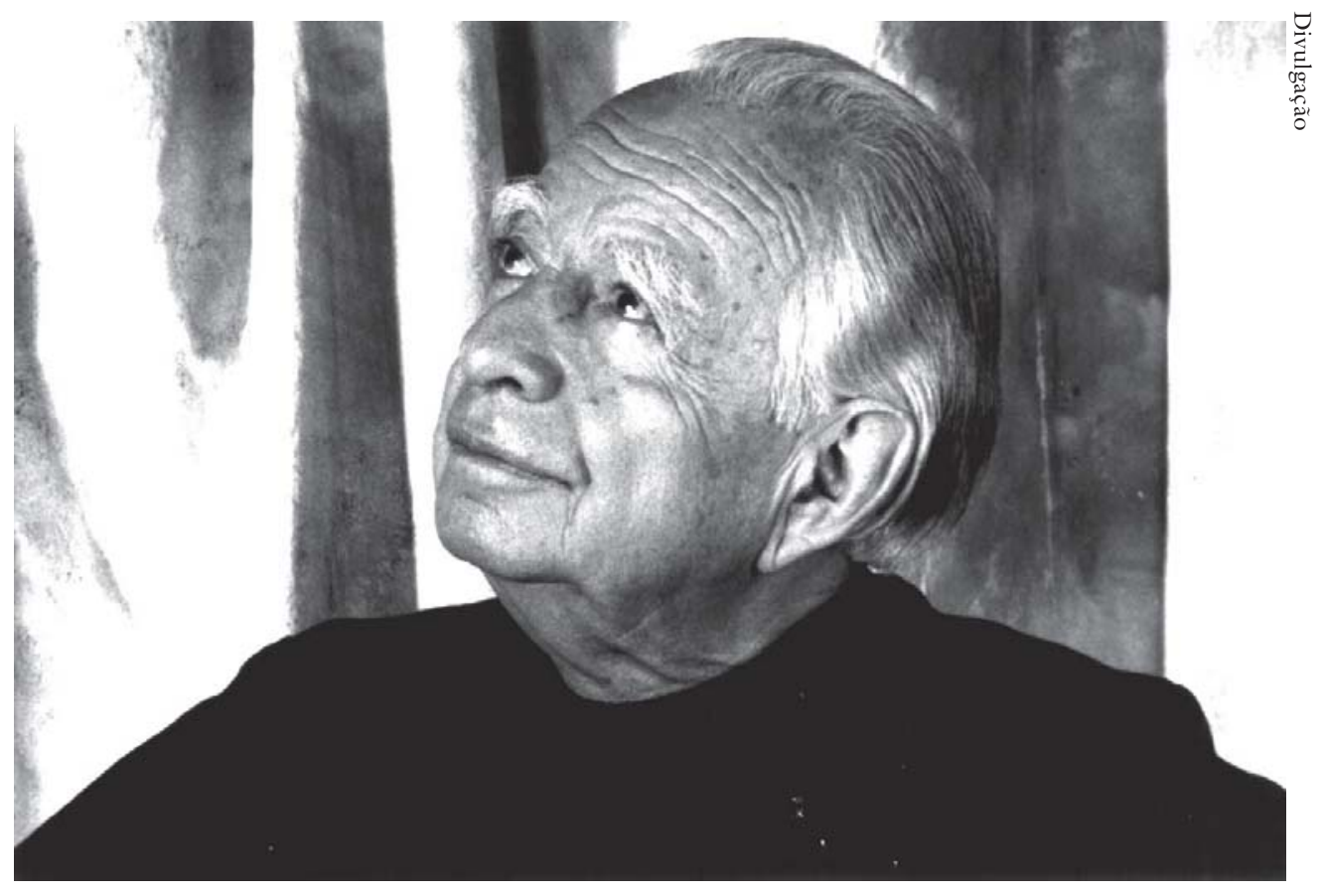

O maestro foi profesxsor visitante do Instituto de Estudos Avançados da USP

No início, segundo ele relembra "discutíamos principalmente os artigos do Andrade Muricy - as críticas que ele escrevia semanalmente no Jornal do Comércio. Eu não tinha meios de participar por causa da língua. 
Mas fui para conhecer pessoas e porque precisava de alunos para levar minha vida". Aos poucos, os encontros foram se tornando diários, "todas as noites, às seis horas, depois de fechado o comércio. O lugar se chamava Pingüim. Era uma loja de discos e música em geral na rua do Ouvidor onde, nos fundos, a gente se reunia: conversávamos, discutíamos e tomávamos café. Vinha o Otávio Bevilacqua, o Luís Heitor, Brasílio Itiberê e tinha também a diretora da área de música da Biblioteca Nacional, D. Mercedes Pequeno".

"Foi coisa romântica daquele tempo: criticávamos a vida cultural... não só a música, mas principalmente...” Lembra dos planos que deram certo e de como divulgavam suas idéias: "tinha o folheto do Grupo. Saíram 12 ou 13, de dois em dois meses e nós pagávamos tudo. O presidente de honra era o Villa-Lobos e participava também o Egídio de Castro e Silva e vários músicos da Orquestra Sinfônica: o Cláudio Santoro, Guerra Peixe, Edino Krieger, Santino Parpinelli, Heitor Alimonda... Éramos todos músicos práticos - mudamos a orientação para dar ênfase à música de nosso tempo. Todos tornaram-se compositores".

Com tantas atividades, tantas histórias, tantas convicções, quem são as pessoas que se encontram, discutem, trocam idéias com Koellreutter? Perguntei assim, para vê-lo através de mais esta perspectiva - das pessoas com quem convivia. "Colegas ou também adversários, que partam de um paradigma holístico; que tenham esta abertura de admitir o adversário, o oposto, se você quiser..." Mas quem seriam? Que nomes, mesmo se apenas uma lembrança afetuosa de momento?

O tempo de silêncio diante dessas perguntas - quase insistentes pareceram-me demasiadamente longos, como se eu perturbasse uma solidão já incorporada. Lembrava de Arnaldo Contier (1991) comentando duas vezes, no mesmo artigo, que Koellreutter havia sido isolado em razão de desdobramentos histórico-musicais do período pós Grupo Música Viva. Mas deixei o silêncio agravar a espera.

Veio a resposta: "principalmente meus discípulos... mas também colegas..." Ficaram outras indagações que poderiam, se explicitadas, adentrar uma área na qual, talvez, apenas mais silêncio viesse como resposta. Com os discípulos, anônimos lembrados, quais eram as idéias mais freqüentes? "Digo a meus discípulos sempre: o debate é mais importante que a solução de problemas. Isto é um princípio que tenho! No fundo, minha filosofia, se você quiser assim, é uma filosofia holística - acho que a opinião do outro é muito importante". 
Mas, havia entendido que o professor não ensina nada...? "Eu exagero certos conceitos para que eles se conscientizem mais... despertam a reação deles". E complementa, já com certas exigências para o professor e para o aluno: "digo que não há coisa errada em arte! Os alunos que vão fazer composição têm sempre medo de errar. Para contra-agir com esta tendência, digo isto! O errado é a incoerência com uma estética que puderem defender. Cada um pode ter sua religião - não interessa se é correto comigo... interessa se têm uma estética, uma concepção...”.

A perspectiva holística também é um “princípio de meu método de ensinar - pedagógico". Parte do conceito de cosmovisão para caracterizar essa sua filosofia de vida, que aspira a uma "integração perceptiva de vários elementos por todos os lados e ao mesmo tempo" levando à "fusão entre níveis de conscientização". É a partir de tal visão que Koellreutter se autodefine: "sou um homem que se interessa não só pela música mas pela interdependência de todas as áreas".

\section{Finalizando, até próximos encontros...}

Nesse vasto campo para o debate, para a construção de estéticas próprias e defensáveis, e para uma certa inutilidade do professor, Koellreutter vê o artista como um ser diferenciado, exigindo dele uma ação distintiva: "se é um homem médio, medíocre, ele nunca vai ser um artista neste sentido de poder transluzir - através de seu estilo - o próprio ser humano. Tem que ser um elemento fora do comum, uma personalidade".

As exigências não são menores com relação ao professor de música. É como se ambos precisassem de uma certa dose de transcendência - para além e para aquém daquela normalidade que significa um pensar e agir previsível, atado a padrões inalteráveis. Na primeira aula, os futuros professores recebem uma instrução, já conhecida, mas sempre difícil de incorporar e manter: "aprendam a aprender das crianças o que vocês devem ensinar".

Além dessa flexibilidade mental, porém - para transcender e para reaprender -, a atividade especulativa também é fundamental na visão pedagógica que Koellreutter defende. Um dos princípios que seus alunos "devem aceitar como condição" para entrar nas suas aulas é o de não acreditar "em nada que pensem.. tudo deve ser colocado em discussão; questionar livros, professores..." Se ele próprio tivesse adotado esse princípio teria resolvido, bem cedo, uma de suas inquietações: "nunca me explicaram o efeito psicológico da nota sensível. Só quando o conceito de tempo em música passa a ter um início e um fim é que surge o conceito de nota sensível... Mas ninguém me explicava isto!” 
Se, como diz Koellreutter, "a história nunca elimina, ela sempre integra", há fatos e idéias em sua vida que ainda precisam ser articulados com sua obra e sua atuação profissional como músico e professor. Num certo momento do primeiro dos nossos encontros, já passadas mais de três horas de falas, Koellreutter comentou: "esta vai ser a entrevista mais difícil da minha vida". Ele não sabia que àquela altura, eu também poderia expressar tal sentimento. Reconheci, em muitas ocasiões, que certos pensamentos deixavam transparecer mundos que só as histórias vividas além dos 80 anos saberiam compreender. Faltava-me essa condição.

Diante de alguém que eu não via como normal, com histórias tão peculiares quanto intrigantes e tendo transformado uma entrevista numa série de encontros prolongados, era natural que a finalização deste trabalho não fosse assim tão clara. Penso que simplesmente paramos num determinado ponto, possível de ser retomado a qualquer momento, num próximo encontro...

Notas

1 Alguns esclarecimentos e/ou detalhes sobre certas informações aqui apresentadas foram oferecidas por Koellreutter, em conversa telefônica, após os encontros e durante a elaboração deste texto.

2 Koellreutter observou que a expressão "filosofia holística" nem sempre é bem aceita entre os adeptos desta perspectiva. "Paradigma" ou "visão holística" têm sido as expressões mais utilizadas.

3 Koellreutter sofreu uma grave intoxicação em decorrência de um trabalho temporário como gravador de partituras em chapas de chumbo.

Referências bibliográficas

CHAVES, C. Loureiro. A música brasileira antes e depois de Koellrentter, set. 1995. Cópia, cedida por H.J. Koellreutter [versão preliminar].

CONTIER, Arnaldo. Memória, história e poder: A sacralização do nacional e do popular na música (1920-50). Revista Música. São Paulo, Departamento de Música da Escola de Comunicações e Artes da Universidade de São Paulo, v. 2, n. 1, p. 5-36, maio 1991.

DUARTE JR., João Francisco. A política da loucura. Campinas, Papirus, 1987. 
KOELLREUTTER, Hans-Joachim. O caminho da superação dos opostos. MúsicaHoje - Revista de Pesquisa Musical. Belo Horizonte, Núcleo de Apoio à Pesquisa e Centro de Pesquisa em Música Contemporânea da Escola de Música da Universidade Federal de Minas Gerais, n. 2, p. 7-26, 1995.

A nova imagem do mundo: estética, estruturalismo e planimetria. Revista Música. São Paulo, Departamento de Música da Escola de Comunicações e Artes da Universidade de São Paulo, v. 2, n. 2, p. 85-90, 1991.

Introdução à estética e à composição musical contemporânea.

ZAGONEL, B. \& CHIAMUlERA, S. (orgs.). Porto Alegre, Editora Movimento, 1984.

MENDES, Gilberto. Música moderna brasileira e suas implicações de esquerda. Revista Música. São Paulo, Departamento de Música da Escola de Comunicações e Artes da Universidade de São Paulo, v. 2, n.1, p. 37-42, maio 1991.

SQUEFF, Enio. A música contemporânea brasileira e o Brasil. ART. Salvador, Escola de Música e Artes Cênicas da Universidade Federal da Bahia, v. 13, p. 73-83, abr. 1985.

Irene Tourinho é doutora em Educação Musical pela Universidade de WisconsinMadison, professora do Departamento de Música da Escola de Comunicações e Artes da Universidade de São Paulo e professora visitante do mestrado em Artes - Música e Artes Visuais - da Universidade Federal de Goiás 